\title{
PSYCHOLOGICAL TRAINING OF A SHOOTER
}

\author{
Kostyantyn Zadorozhniyl \\ National Academy of National Guard of Ukraine, Kyiv, Ukraine \\ ${ }^{1}$ Educator, Department of service-combat operations of units of National Guard of Ukraine
}

Background: In the course of training sessions with military personnel, attention should be paid to such an important point of training as the psychological preparation of the arrow. It is known that the pre-launch condition causes the corresponding changes in the body, which can adversely affect the ability of the shooter, demonstrate high firing technique and achieve high results.

Purpose: to study relations between psychological conditions of a shooter and changes in the technique of shooting

Methods: theoretical review of the researches on psychological peculiarities of shooters; observation and monitoring of the students in military HEI

Results: The most significant negative characteristic of the shooter's psychophysiological state before firing, which have the greatest impact on its results, are: an increase in heart rate to 100-140 beats per minute; local relaxation of the muscles of the hands, shins, etc ; sweating of the palm; impaired movement coordination; loss of stability of body position; increase in arm swing with arms; increase in tremor of hands; impaired vision; slow or accelerated response, etc.

Conclusion: The psychological state of the shooter imposes a significant imprint on the technique of shooting. The relationship between changes in the technique of shooting and the psychological state of the shooter depends on his individual characteristics. The psychological training tools used in the training of shooters are: firing on a task (the shooter is invited to perform a certain number of shots with a specific result); training in techniques of autogenous training; performing various group exercises; firing; training after exercise (jogging, squats, stretching, etc.); modeling of extreme conditions characteristic of the shooter's activity during shooting.

Keywords: militarians, shooter, psychphysiology, psychological reactions, psychologica;1 conditions of a shooter

Психологічна підготовка - це не окрема частина підготовки стрільця. Вона органічно входить в усі розділи технічної підготовки та виховання і не може розглядатися автономно. Але для зручності засвоєння цих питань вона виділена в самостійний розділ.

Психологічна підготовка стрільця - це процес, спрямований на створення його оптимального психологічного стану та формування постійної внутрішньої готовності, яка сприяє реалізації найбільш досконалої техніки стрільби в умовах стресових ситуацій (Бодров, 2000).

Основними завдання емоційної підготовки стрільця - створення ентузіазму і любові до стрільби, готовності до тренувальної та змагальної активності, що вимагає вольових зусиль для подолання зовнішніх і внутрішніх перешкод, поліпшення психологічних параметрів особи, формування і поліпшення інтелекту спортсмена. Вдале укладання цих задач залежить від знань і педагогічного професіоналізму тренера, від володіння спортсменами системою особливих знань про нервову систему людини. Спортсмени зобов'язані знати, що це сприйняття, уявлення, інтерес, його види та характеристики, пам'ять, мислення, свобода, вольові властивості, відчуття, враження, який їхній сенс, роль і вплив на активність людини. Важливішою з головних задач емоційної підготовки вважається набуття стану готовності до змагань, що виражається в змобілізованості спортсмена на виконання встановлених завдань. Особливо це важливо перед серйозними, основними змаганнями. Мобілізовуватись необхідно навчатися при вирішенні щоденних завдань, у процесі навчально-тренувальних занять безперервно, день у день (Айзенк, 2003).

Розглянувши основні питання навчання стрільб, слід акцентувати увагу на такому важливому моменті навчання, як психологічна підготовка стрілка (Ануфрієв та ін., 2003). У процесі навчально-тренувальних занять часто доводиться спостерігати, наскільки впевнено в 
кабінеті стрільці поводяться 3 навчальною зброєю. На вогневому рубежі - зовсім інша ситуація. Деякі стрільці, досить сильно стискаючи в руці пістолет, заряджений бойовими патронами, виглядають розгубленими й скутими. Стрільба 3 пістолета асоціюється в них 3 почуттям страху, який часом домінує в роботі центральної нервової системи. Ці почуття загальмовують всю іiі функціональну діяльність і викликають стан зайвої напруженості психіки й усіх систем організму стрільця (Барко, 2002).

Відомо, що передстартовий стан викликає відповідні зміни в організмі, які можуть негативно впливати на здатність того, хто стріляє, продемонструвати високу техніку стрільби і досягти високого результату.

Найбільш характерними ознаками стану стрільця перед початком стрільби, що найбільшою мірою впливають на іiі результати, є: збільшення частоти пульсу до 100-140 ударів у хвилину ; локальне розслаблення м'язів кистей рук, гомілок і т. ін.; потіння долоні; порушення координації рухів ("палець не тисне"); втрата стійкості положення тіла; збільшення коливання руки зі зброєю; збільшення тремору рук; погіршення зору; уповільнена чи прискорена реакція тощо.

Усі зміни, що відбуваються в організмі стрільця перед стрільбою, накладають значний відбиток на техніку стрільби, тобто руйнують слабо закріплену навичку. Наприклад, можуть відбуватися наступні зміни в техніці стрільби: зміна часу прицілювання (в основному збільшення); у стрільбі по рухомих цілях зменшення точності піднімання руки зі зброєю на першу мішень і при наступному переносі зброї; зміна характеру натиску на спусковий гачок; різке чи занадто повільне піднімання руки при стрільбі по мішенях, що з'являються; зменшення амплітуди коливань зброї; зміна темпу стрільби тощо. (Баронін, 2001) До нової концепції юридичної освіти Взаємозв'язок між змінами в техніці стрільби й психологічним станом стрільця залежить від його індивідуальних особливостей, рівня підготовленості, а також від інших умов, в яких він знаходиться. Досвідчені стрільці можуть управляти своїм психологічним і психофізичним станом і показувати стабільні й високі результати стрільби. Ця здатність виробляється в процесі навчально-тренувальних занять, на яких одночасно вдосконалюється техніка стрільби (Бруксміт, 2004).

Взаємозв'язок між станом стрільця і змінами в техніці стрільби індивідуальний і залежить від ступеню підготовки стрілка.

Досвідчені стрільці можуть керувати своїм станом і показувати високі й стабільні результати. Цю здатність вони виробляють у процесі тренувань, на яких удосконалюють техніку стрільби одночасно з психологічною підготовкою.

Відомо, що зовсім спокійний стан не сприяє максимальному прояву всіх навичок i якостей, якими володіє стрілець.

Необхідно, щоб психічний стан перед стрільбою і під час відповідальних стрільб мав оптимальний рівень хвилювання. Такий психологічний стан називається станом бойової готовності. Саме в ньому у стрільця найбільшою мірою виявляються і загострюються усі відчуття, координація дій i рухів, технічні навички. Тому, щоб керувати процесом підвищення влучності стрільби, необхідно опанувати всім комплексом засобів і методів психологічної підготовки.

Стрілець повинен навчатись умінню впливати на себе, зосереджуватися на головному в стрільбі, розвивати сміливість, рішучість, працьовитість, старанність.

У психологічній підготовці стрільця значну роль відіграє заохочення. Тому, кого навчають, необхідно нагадати, що успіх прийшов завдяки його наполегливості, працьовитості, що виявилися під час тренувань.

Заохочення не повинно створювати в того, кого навчають, думку про його обдарованість, про те, що він не такий, як інші в колективі.

Зрозуміло, що заохочуючи одного ми стимулюємо цим інших.

Негативно впливають на стрільців шуми (постріли сусідів по вогневому рубежу, розмови за спиною і т.п.) під час стрільби. Тому необхідно виховувати уміння зосередитися на 
контролі своїх дій, відключитися від усього стороннього, що відволікає увагу від виконання влучного пострілу.

Формування концентрованої уваги, зосередженості досягається в першу чергу самовихованням. У будь-якій справі треба намагатися думати лише про досягнення поставленої мети.

Виконуючи вправу, намагаючись досягти високого результату, стрілець сприймає пробоїну в мішені у вигляді визначеної цифрової цінності (десятка, дев'ятка і т.д.) Сума результатів пострілів залежить від кількості пробоїн у "десятку" i, звичайно, стрілець мимоволі починає думати про неї. Однак через це він, непомітно для себе, послаблює контроль за точним виконанням елементів циклу пострілу. Відбувається погоня за "десяткою", і з'являється невдала пробоїна як наслідок втрати уваги. А невдала пробоїна породжує невпевненість при черговому пострілі. Необхідно переконати себе в тому, що поганий постріл - це ще не поразка, але сигнал про виникнення порушень і помилок у діях.

Переконайте себе в тому, що при правильному виконанні прицільного пострілу гарантований високий результат. В уяві “прокрутіть” весь цикл пострілу. Звичайно, можливі й інші способи, що позитивно діють на нервову систему.

Досягти високих результатів допомагає впевненість у своїх силах. Необхідно стріляти спокійно, дивитися на "десятку" без тремтіння перед результатом.

Для подолання психологічного бар'єру як засобу нервової напруги, що знижує загальний результат, можна рекомендувати наступну вправу: глибоко вдихнути, затримати подих на 56 сек. Напружити м'язи, потім повільно видихнути й одночасно розслабити якнайбільше м'язи всього тіла. Вправу повторити декілька разів.

Безумовно шкідливо для стрільців, особливо в період тренувань і підготовці до стрільби, паління. Дія випаленої цигарки різко збільшує всі негативні ознаки нервового розладу.

Неважко запам'ятати поради 3 того чи іншого питання, важко їх виконувати. Але наполегливість, заснована на самовихованні, допоможе досягнути поставленої мети.

Самовиховання повинно бути спрямоване на розвиток здатності керувати своєю поведінкою і психічним станом.

Вихідний момент самовиховання волі - пізнання самого себе, визначення своїх сильних $\mathrm{i}$ слабких сторін. Саме тут якості самокритичності виявляються особливо повно. Нерідко помилкове самолюбство заважає стрільцю визнати й об'єктивно оцінити свої недоліки. Однак це необхідно: чим яскравіше стрілець бачить сутність своїх недоліків, тим конкретніше він буде вживати заходи щодо їхнього виправлення і тим легше вирішувати ці завдання.

Комплексна підготовка стрільця 3 урахуванням основних факторів надійності його психологічної підготовки дозволить зменшити вплив негативних факторів на стан стрільця і стабілізувати техніку стрільби.

Тому завдання підвищення сталості техніки стрільби і надійності в досягненні наміченого результату включає:

1. Оволодіння стійкою i найбільш раціональною технікою стрільби; тренування стійкості нервової системи та їі незалежності від впливу результатів стрільби, виконаних послідовно;

2. Відпрацювання спеціальних технічних прийомів, що нормалізують рівень техніки стрільби;

3. Формування спеціальних фізичних якостей, що забезпечують багаторазове виконання стрілецьких вправ;

Засобами психологічної підготовки, що використовуються при підготовці стрільців є: стрільба на завдання (стрільцю пропонується виконати визначену кількість пострілів 3 визначеним результатом); навчання прийомам аутогенного тренування; виконання різних групових вправ; контрольна стрільба; тренування після фізичного навантаження (бігу, присідань, підтягування тощо); моделювання екстремальних умов, характерних для діяльності стрільця в період проведення стрільб. 
Комплексна підготовка 3 урахуванням основних факторів надійності його психологічної підготовленості дозволяє стабілізувати техніку стрільби в період відповідальних стрільб. Отже, поряд з аспектами фізичної підготовки й умінням застосовувати особисту зброю в критичних ситуаціях при підготовці стрільця належним чином повинна бути здійснена і його психологічна підготовка (Резанов, 2004).

\section{References}

Aisenk (2003), Supertests of IQ - M. Exmo

Anufriev M., Irhin Yu., Kurko M., Nescheret T., Omelchenko S., Synivskiy V., Shapovalov O. (2003) Professiographical characteristics of main types of activities in Police services of Ukraine $\backslash 1$

Barko V. (2002) Professional selection of personnel for Police services (psychological aspect) $\backslash$ monography

Baronin A. (2001) Psychological profile of killers $\|$ guidance on criminal psychology and criminalistic

Bodrov V. (2000) Informational stress \ guidance for students - M.

Bruksmit P. (2004) Art of sniper training - M.

Resanov O. (2004) History of sniper' art - M. Bratyka

\section{Список використаних джерел}

Айзенк Г. Супертесты IQ. - М.: Изд-во Эксмо, 2003. - 208 с.

Ануфрієв М.І., Ірхін Ю.Б., Курко М.Н., Нещерет Т.В., Омельченко С.В., Синівський В.В., Шаповалов О.В. Професіографічна характеристика основних видів діяльності в органах внутрішніх справ України (кваліфікаційні характеристики професій, професіограми основних спеціальностей): Довідник. - К.: МВС України; КIBC, 2003. - 80 с.

Барко В.I. Професійний відбір кадрів до органів внутрішніх справ (психологічний аспект): Монографія. - К.: Ніка-Центр, 2002. - 296 с.

Баронін А.С. Психологічний профіль вбивць. Посібник 3 кримінальної психології та криміналістики. - К., Вид. ПАЛИВОДА. А.В., 2001. - 176 с.

Бодров В.А. Информационный стресс: Учебное пособие для вузов. - М.: ПЕРСЗ, 2000. - 352 с.

Бруксмит П. Искусство снайперской подготовки / Пер. с англ. В.А. Гришечкина. Под редакцией Ю.В. Шокарева. - М: ООО “Издательство “РОСМЗНПРЕСС”, 2004. - С. 131.

Олег Резанов. История снайперского искусства. - М.: Братика, 2004. - 160 с.

\section{Contact information}

Kostyantyn Zadorozhniy innulka7777@gmail.com 